\title{
Pengembangan Film Animasi dalam Pembelajaran Fisika pada Materi Kesetimbangan Benda Tegar di SMA
}

\author{
Firma Rean Kasih \\ Program Studi Pendidikan Fisika, STKIP Yayasan Dharma Bakti; email: firmareankasih@gmail.com
}

Diterima: 1 Mei 2017. Disetujui: 22 Mei 2017. Dipublikasikan: Juni 2017

\begin{abstract}
This study aims to produce a physics film animation on the topic of equilibrium of rigid body which is valid, practical and effective. The type of research used is research and development and the object are a film animation and the students of class XI IAI SMAN 1 Lubuk Alung. The research procedures include: identifying potentials and problems, gathering information, developing designs, validating designs, revising designs, and piloting product. The data collection instrument consists of: expert's validation sheet, observation sheet, teacher and student questionnaire, and objective test sheet. Data analysis technique used are data interpretations in graphs, descriptive analysis and correlation comparison test. The results present that the design of the animated film is feasible with validity value 4.37. The using of animation film is very practical with the percentage of practicality $90.17 \%$. Therefore, the film is effective, shown by a significant increase in learning outcomes in the cognitive domain.
\end{abstract}

\begin{abstract}
Abstrak
Penelitian bertujuan menghasilkan film animasi fisika pada materi kesetimbangan benda tegar yang valid, praktis dan efektif. Jenis penelitian yang digunakan adalah jenis penelitian dan pengembangan dengan objek penelitian adalah film animasi dan siswa kelas XI IA1 SMAN 1 Lubuk Alung. Prosedur penelitiannya meliputi: mengenal potensi dan masalah, mengumpulkan informasi, mengembangkan desain, memvalidasi desain, merevisi desain, dan uji coba produk. Instrumen pengumpul data terdiri dari: lembar validasi tenaga ahli, lembar observasi keterlaksanaan, angket respon guru dan siswa, dan tes hasil belajar siswa. Teknik analisis data yang digunakan adalah interpretasi data dalam grafik, analisis deskriptif, dan uji perbandingan berkorelasi. Hasil penelitian menunjukkan bahwa desain film animasi layak dengan nilai kevalidan 4,37. Penggunaan film animasi sangat praktis dengan persentase kepraktisan 90,17\%. Terakhir, penggunaan film animasi efektif ditandai dengan peningkatan hasil belajar yang berarti pada ranah kognitif.
\end{abstract}

Kata kunci: film animasi, kesetimbangan benda tegar, fisika, validitas, efektivitas

(ㄷ) 2017 URPI, FTK UIN Raden Intan Lampung

\section{PENDAHULUAN}

Fisika adalah salah satu mata pelajaran wajib di SMA untuk program studi ilmu alam. Salah satu konsep dalam standar isi mata pelajaran fisika adalah kesetimbangan benda tegar. Materi kesetimbangan benda tegar diajarkan di SMA kelas XI semester 2 dengan indikator yang harus dikuasai siswa antara lain: mampu menjelaskan tentang syarat-syarat suatu benda bisa berada dalam keadaan setimbang, mendeskripsikan titik berat dan hubungannya dengan pusat massa, membedakan jenis-jenis kesetimbangan (stabil, labil, dan netral) serta aplikasinya dalam pemecahan masalah dalam kehidupan sehari-hari.

Kesetimbangan benda tegar merupakan salah satu materi fisika yang cukup kompleks karena merupakan gabungan dan aplikasi dari beberapa materi yang harus dikuasai sebelumnya. Beberapa materi prasyarat yang harus dikuasai siswa antara lain vektor, Hukum Newton dan dinamika rotasi. Oleh karena itu, dalam penyelesaian soal-soal siswa tidak cukup hanya dengan menghapalkan rumus saja tapi harus mampu menganalisa letak, besar, dan arah gaya maupun torsi. Hal seringkali 
menyebabkan siswa yang belum memahami konsep kebingungan dalam menyesaikan soal, karena tiap soal yang berbeda, berbeda pula penyelesaiannya.

Materi kesetimbangan benda tegar menuntut penalaran yang tinggi mengenai gerakan rotasi serta gambaran yang jelas mengenai titik berat. Materi ini membutuhkan pemahaman konsep yang kuat disamping kemampuan matematis yang tinggi pula. Hal ini menimbulkan kesan negatif bagi siswa yang kesulitan dalam memahami materi tersebut. Penjabaran materi di kelas yang terkesan jauh dari kehidupan keseharian semakin menambah sikap negatif siswa terhadap fisika.

Beberapa cara untuk mengubah persepsi negatif tentang fisika antara lain: menghubungkan fisika dengan kegiatan yang menyenangkan, belajar bukan dengan penghafalan rumus, melainkan memahami penurunan rumus, dan memanfaatkan berbagai alat peraga dan multimedia agar pelaksanaan proses pembelajaran fisika efektif, efisien, dan menarik. Oleh karena itu, pemilihan media pembelajaran fisika yang tepat sangatlah penting.

Media belajar yang baik adalah media yang menyenangkan dan mudah dicerna. Komik sangat diminati baik anak-anak, remaja, maupun dewasa. Penggunaan komik terbukti efektif karena gambar lebih mudah diingat dan memicu imajinasi siswa sehingga lebih bersemangat dalam belajar. Penelitian yang telah dilakukan oleh Nugroho yang berjudul Pengaruh Penggunaaan Media Kartun Terhadap Hasil Belajar Siswa Kelas I SLTPN 3 Batusangkar, serta penelitian (Netty, 2005) mengenai Penggunaan Komik Biologi di SMUN 2 Angkat Candung Bukittinggi dapat meningkatkan hasil belajar siswa secara signifikan pada taraf kepercayaan 95\% (Nugroho, 2003). Selanjutnya penelitian hibah bersaing oleh (Mulyardi, 2006) yang berjudul Pengembangan Model Pembelajaran Matematika dalam Bentuk Komik pada Sekolah Dasar di Kota Padang menyatakan bahwa siswa tertarik untuk belajar matematika menggunakan media komik. Selain itu, media pembelajaran komik juga bisa dikembangkan dalam platform sosial media seperti Instagram (Irwandani \& Juariyah, 2016).

Media komik diyakini cocok untuk beberapa mata pelajaran akan tetapi tidak untuk pelajaran yang membutuhkan gambaran jelas dan konkrit mengenai gerak dan proses pada fisika. Untuk itu komik tersebut dapat dijadikan film kartun. Film kartun atau film animasi mampu menjelaskan sesuatu yang rumit atau komplek dibandingan dengan hanya menggunakan gambar atau kata-kata saja. Pembelajaran berbantuan film animasi terbukti bisa meningkatkan motivasi siswa (Mukhlishoh \& Khisbiyah, 2015) dan meningkatkan kemampuan menyimak dan berbicara (Istova \& Hartati, 2016).

Film merupakan bagian dari media komunikasi massa yang memiliki pengaruh yang besar dalam masyarakat. Hal ini dikarenakan film mempunyai kemampuan untuk menarik perhatian orang serta kemampuan mengantarkan pesan secara unik (Mc Quail, 1997). Selain berfungsi sebagai hiburan,film juga dijadikan sebagai sarana untuk menyampaikan suatu informasi bagi audiennya. Berbagai informasi yang disampaikan dalam media film diantaranya kehidupan sosial, budaya, politik, dan dunia ilmiah, memiliki peranan penting dalam pembelajaran masyarakat.

Berdasarkan hasil survei dari PUSTEKOMDIKNAS tahun 2008 dengan menggunakan kuesioner pada anak umur 713 di Surabaya menyatakan bahwa $74 \%$ anak-anak lebih menyukai film kartun atau animasi daripada yang bukan animasi. Jika penggunaan komik mampu meningkatkan kemampuan dan minat siswa dalam pembelajaran secara signifikan, maka penggunaan animasi diyakini akan semakin meningkatkan minat, motivasi dan pemahaman siswa mengenai fisika.

Bertolak dari masalah dan potensi yang telah diuraikan diatas, maka penulis merancang dan mengembangkan film 
animasi dalam pembelajaran fisika pada materi kesetimbangan benda tegar dan mengetahui tingkat validitas, praktikalitas, dan efektivitasnya.

\section{METODE PENELITIAN}

Penelitian ini menggunakan jenis penelitian Research and Development (penelitian dan pengembangan) (Sugiyono, 2006). Produk yang dihasilkan dalam penelitian ini adalah dalam bentuk film animasi. Terdapat dua hal yang menjadi objek penelitian. Objek penelitian pertama film animasi dalam pembelajaran fisika pada materi kesetimbangan benda tegar. Film animasi dalam pembelajaran fisika pada materi kesetimbangan benda tegar divalidasi oleh dosen fisika Universitas Negeri Padang dan ditanggapi oleh guru fisika SMAN 1 Lubuk Alung, kemudian diperbaiki dan diujicobakan dalam skala terbatas. Objek kedua adalah siswa kelas XI SMAN 1 Lubuk Alung yang terdaftar pada semester Januari-Juni 2011. Kelas yang digunakan adalah kelas XI IA1 dengan jumlah siswa 28 orang. Pada siswa diberikan tes awal untuk mengetahui kemampuan awal siswa sebelum diberi perlakuan. Perlakuan yang diberikan adalah pembelajaran dengan menggunakan film animasi. Setelah itu siswa diberi tes akhir untuk mengetahui efektivitas penggunaan film animasi dalam pembelajaran fisika pada materi kesetimbangan benda tegar.

Secara umum langkah-langkah penelitan yang dilakukan adalah menentukan potensi dan masalah, mengumpulkan informasi, melakukan pengembangan desain produk, memvalidasi desain, revisi desain, uji coba produk, terkhir melakukan revisi produk.

Instrumen pengumpul data untuk uji validitas desain adalah dengan menggunakan angket dengan beberapa indikator yang mencakup aspek roduk dan aspek instruksional. Skala Likert digunakan untuk melakukan penilaian validitas dari film tersebut (Sudjana, 2001). Instrumen uji praktikalitas terdiri dari lembar observasi pelaksanaan pembelajaran di kelas, angket respon guru, dan angket respon siswa. Angket praktikalitas dideskripsikan dengan teknik análisis frekuensi, dengan menghasilkan kriteria tidak praktis, kurang, cukup, praktis, dan sangat paraktis (Riduan, 2005).

Keefektifan film animasi dalam pembelajaran fisika pada materi kesetimbangan benda tegar dilakukan dalam uji lapangan terbatas, yaitu di kelas XI IA1 SMAN 1 Lubuk Alung. Instrumen pengumpul data untuk uji efektivitas berupa tes hasil belajar kognitif siswa sebelum dan sesudah menggunakan film animasi dalam pembelajaran fisika pada materi kesetimbangan benda tegar. Untuk uji efektivitas ini terlebih dahulu dilakukan analisis instrumen butir soal, dengan menghitung reliabilitas instrumen (Slameto, 2001), tingkat kesukaran,dan daya pembeda butir soal (Surapranata, 2005). Selanjutnya dilakukan dilakukan analisis hasil belajar dengan menghitung validitas tes, reliabilitas tes (Surapranata, 2005), dan uji-t berkorelasi (Hadjar, 1996).

\section{HASIL DAN PEMBAHASAN}

\section{Deskripsi Desain}

Produk yang dihasilkan pada penelitian adalah film animasi dalam pembelajaran fisika pada materi kesetimbangan benda tegar. Media pembelajaran yang dihasilkan dikembangkan dengan menggunakan software Adobe Flash CS4 Profesional dan Cyberlink Power Director. Produk ini dapat digunakan dalam pembelajaran fisika pada kelas XI IPA di SMA. Selain penggunaan di dalam kelas, film animasi juga dapat digunakan di luar kelas secara mandiri baik oleh siswa maupun guru.

Film animasi ini disimpan dalam keping DVD dan dalam format DVD video sehingga dapat diputar di DVD player biasa. Pada film animasi ini terdapat sepuluh episode yang dapat dipilih sesuai dengan keinginan, antara lain Intro, Pengertian Benda Tegar, Syarat Kesetimbangan, 
Mencari Titik Berat, Mencari Titik Berat Kuantitatif, Jenis Kesetimbangan, Kesetimbangan Botol Shampoo, Kesetimbangan Jungkat-Jungkit, Kesetimbangan Tangga, dan End. Cuplikan beberapa episode pada film animasi terdapat pada Gambar 1 dan Gambar 2.

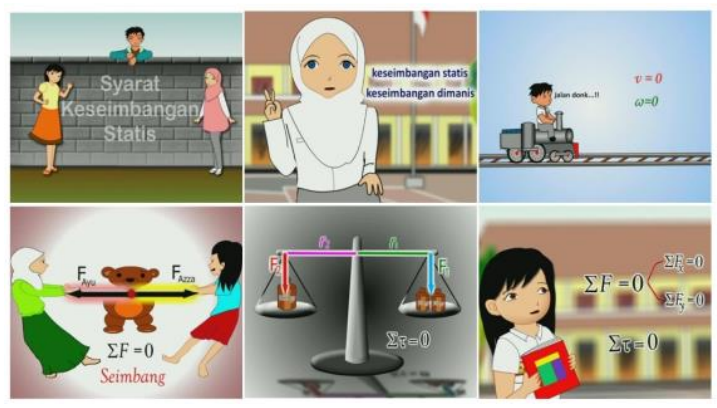

Gambar 1. Cuplikan film animasi pada episode "Syarat Kesetimbangan Statis"

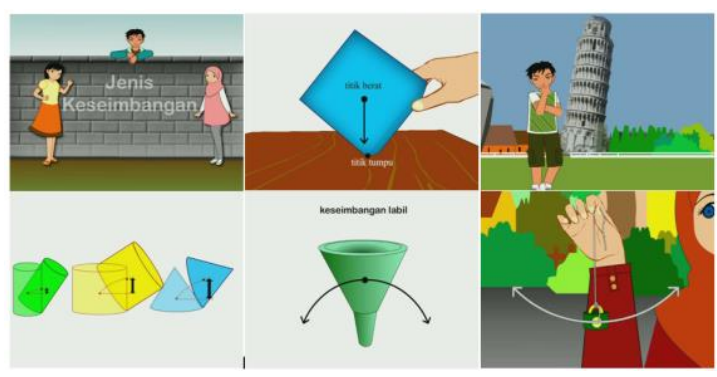

Gambar 2. Cuplikan film animasi pada episode "Jenis Kesetimbangan"

\section{Hasil Validasi dan Praktikalitas Film Animasi dalam Pembelajaran Fisika}

Data lembaran validasi film animasi yang dinilai oleh dosen fisika mencakup aspek, yaitu aspek produk dan aspek instruksional. Hasil plot kelayakan pada aspek produk ditampilkan pada Gambar 3 dan aspek instruksional pada Gambar 4. Dari hasil analisis terhadap lembar validasi tenaga ahli didapatkan nilai validitas ratarata adalah sebesar 4,37. Hal ini mengindikasikan bahwa produk yang dihasilkan adalah berada dalam kategori sangat valid untuk digunakan dalam proses pembelajaran Fisika di kelas XI IA SMA.

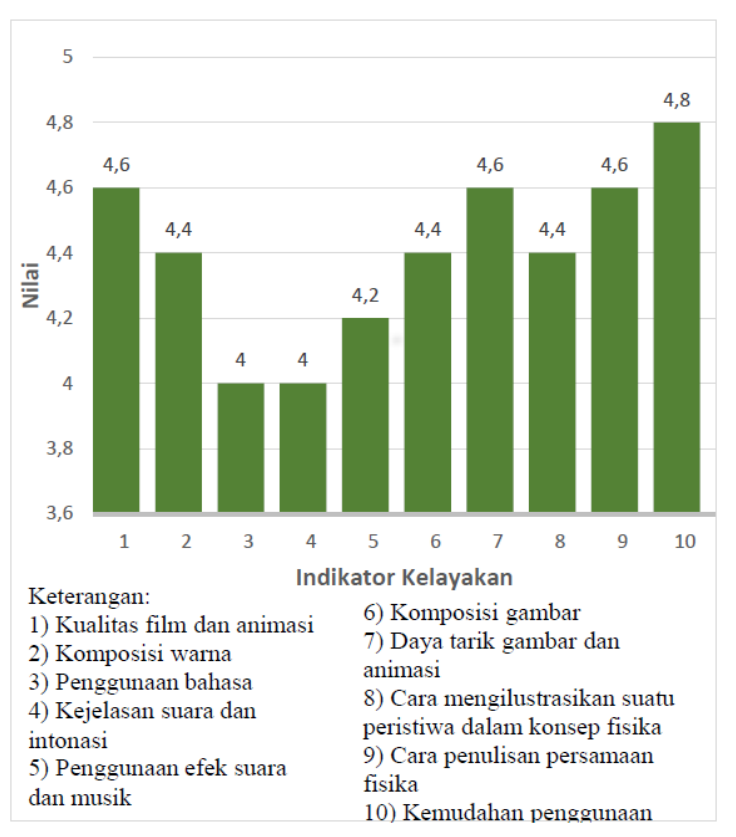

Gambar 3. Plot kelayakan pada aspek produk

Revisi desain dilakukan pada penambahan materi dan penekanan pada konsep kesetimbangan. Antara lain penambahan sedikit materi untuk melengkapi film animasi dalam pembelajaran fisika. Selain materi, juga dilakukan perbaikan pada suara dan musik latar, dimana digunakan musik latar yang lebih energik agar memacu semangat siswa di kelas. Untuk aspek lainnya, desain film animasi dalam pembelajaran fisika secara umum bisa dikategorikan baik.

Pada uji praktikalitas diperoleh hasil untuk lembar observasi, penggunaan film animasi dalam pembelajaran fisika di sekolah terlaksana dengan baik dengan persentase keterlaksanaan 90\%. Hasil penilaian respon guru mengenai film animasi diperoleh sebesar $96 \%$, sedangkan untuk penilian respon siswa, diperoleh nilai 84,52\%. Dari hasil observasi keterlaksanaan, respon guru, dan respor siswa diperoleh rata-rata nilai praktikalitas film animasi dalam pembelajaran fisika sebesar $90,17 \%$ atau berada dalam kategori sangat praktis. 


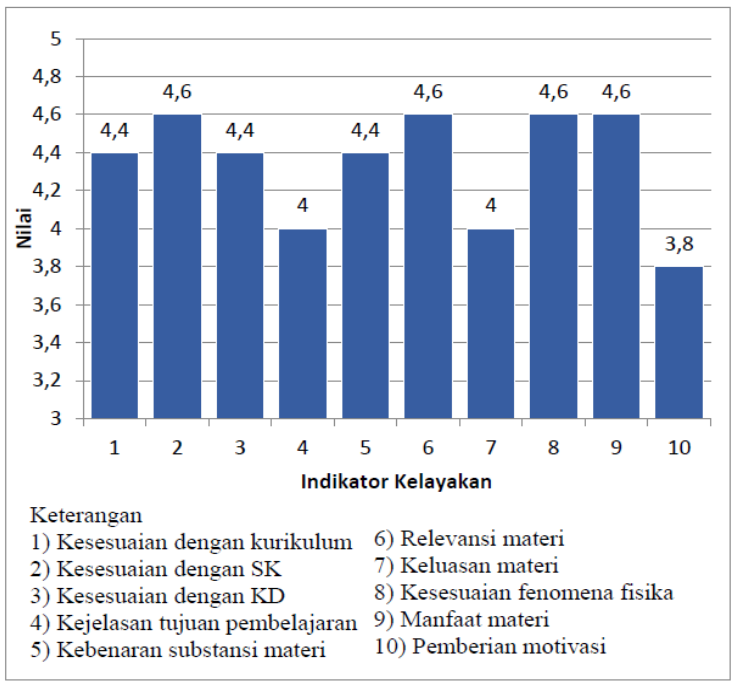

Gambar 4. Plot kelayakan pada aspek instruksional

\section{Hasil Uji Efektivitas Penggunan Film Animasi dalam Pembelajaran Fisika}

Keefektifan film animasi dalam pembelajaran fisika pada materi kesetimbangan benda tegar dilihat dari hasil belajar kognitif siswa dengan menggunakan metoda ekuivalen, yaitu melakukan tes sebelum perlakuan (tes awal) dan tes setelah perlakuan (tes akhir). Butir soal pada tes awal dan tes akhir relatif sama dalam hal tujuan, tingkat kesukaran, serta susunan. Tes awal dan tes akhir berupa 15 butir soal objektif dengan lima pilihan, yang memiliki validitas cukup dan reliabilitas yang tinggi. Hasil analisis data dapat dilihat pada tes awal diperoleh nilai rata-rata sebesar 45,65 , median sebesar 47, modus sebesar 53, varians sebesar 60,89, simpangan baku sebesar 7,80, nilai tertinggi 33 dan nilai terendah 53,33. Sementara, untuk tes akhir diperoleh nilai rata-rata sebesar 88,57 , median sebesar 93,33, modus sebesar 100, varians sebesar 216,81, simpangan baku sebesar 14,72 , nilai terendah 40 , dan nilai tertinggi 100.

Dari data tersebut disimpulkan secara sementara bahwa penggunaan film animasi dalam pembelajaran fisika pada materi kesetimbangan benda tegar dapat meningkatkan hasil belajar siswa. Harga varians yang didapatkan pada tes akhir lebih besar daripada tes awal. Hal ini berarti nilai siswa yang didapatkan pada tes akhir lebih bervariasi. Dari tabel juga terlihat bahwa nilai rata-rata tes akhir lebih tinggi daripada nilai rata-rata tes awal. Simpangan baku menyatakan penyimpangan nilai siswa dari nilai rata-rata. Dari data yang didapatkan dapat diamati bahwa simpangan baku tes akhir lebih besar daripada simpangan baku tes awal. Hal ini berarti penyimpangan nilai siswa pada tes akhir dari nilai rata-rata cukup besar.

Analisis perbandingan rata-rata berkorelasi digunakan untuk melihat keberartian perbedaan antara hasil belajar sesudah dan sebelum penggunaan film animasi dalam pembelajaran fisika. Dengan menggunakan persamaan dan aplikasi pengolah data statistik pada Microsoft Excel diperoleh pearson correlation (koefisien korelasi Pearson), $r$ sebesar 0,66 dan berada pada kategori tinggi. Dengan kata lain reliabilitas atau keajegan tes awal dengan tes akhir tinggi. Hasil dari tes awal dan tes akhir memiliki taraf kepercayaan yang tinggi karena memberikan hasil yang tetap atau sepadan.

Dalam penelitian ini dirumuskan hipotesis sebagai berikut:

$\mathrm{H}_{0}$ : Efektivitas penggunaan film animasi dalam pembelajaran fisika pada materi kesetimbangan benda tegar lebih kecil atau sama dengan sebelum penggunaan film animasi

Ha : Efektivitas penggunaan film animasi dalam pembelajaran fisika pada materi kesetimbangan benda tegar lebih baik daripada sebelum penggunaan film animasi

$$
\begin{aligned}
& H_{0}: \mu_{\text {awal }} \geq \mu_{\text {akhir }} \\
& H_{a}: \mu_{\text {awal }}<\mu_{\text {akhir }}
\end{aligned}
$$


Pada penelitian ini digunakan $t$ critical one-tail atau uji t sepihak yaitu uji pihak kiri. Harga $t_{\text {critical }}$ sebesar 1,70, sedangkan harga $t_{\text {stat }}$ sebesar $-20,27$. Taraf signifikan yang digunakan 0,05 sedangkan $P(T \leq t)_{\text {one-tail }}$ diperoleh sebesar $3,64 \times 10^{-18}$, dimana

$$
\begin{gathered}
\left|t_{\text {critical }}\right|<\left|t_{\text {stat }}\right| \\
|1,70|<|-20,27| \\
\text { atau } \\
P(T \leq t)_{\text {one-tail }}<\alpha \\
3,64 \times 10^{-18}<0,05
\end{gathered}
$$

Sehingga dapat disimpulkan $\mathrm{H}_{0}$ ditolak atau terima $\mathrm{H}_{\mathrm{a}}$. Hal ini menunjukkan bahwa penggunaan film animasi terbukti efektif dalam pembelajaran fisika pada materi keseimbaangan benda tegar.

\section{SIMPULAN DAN SARAN}

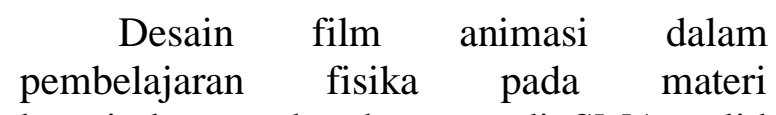
kesetimbangan benda tegar di SMA valid dan layak berdasarkan penilaian ahli. Film animasi sangat praktis penggunaannya dalam pembelajaran fisika pada materi kesetimbangan benda tegar di SMA. Dari hasil observasi keterlaksanaan, respon guru, dan respor siswa diperoleh rata-rata nilai praktikalitas film animasi dalam pembelajaran fisika berada dalam kategori sangat praktis. Film animasi juga efektif penggunaannya dalam pembelajaran fisika pada materi kesetimbangan benda tegar ditandai dengan adanya peningkatan hasil belajar yang berarti pada ranah kognitif.

Berdasarkan hasil penelitian dan pembahasan, maka film animasi dalam pembelajaran fisika pada materi kesetimbangan benda tegar dapat digunakan oleh guru sebagai salah media pembelajaran di SMA. Selanjutnya materi dalam film animasi fisika perlu dikembangkan lagi untuk materi fisika yang lainnya.

\section{DAFTAR PUSTAKA}

Hadjar, I. (1996). Dasar-Dasar Metodologi Penelitian Kuantitatif dalam Pendidikan. Jakarta: Raja Grafindo Persada.

Irwandani, I., \& Juariyah, S. (2016). Pengembangan Media Pembelajaran Berupa Komik Fisika Berbantuan Sosial Media Instagram sebagai Alternatif Pembelajaran. Jurnal Ilmiah Pendidikan Fisika Al-Biruni, 5(1), 33. https://doi.org/10.24042/jpifalbiruni.v5 i1.103

Istova, M., \& Hartati, T. (2016). Pengaruh Media Film Animasi Fiksi Islami untuk Meningkatkan Kemampuan Menyimak dan Berbicara Siswa Sekolah Dasar. Jurnal Pendidikan Sekolah Dasar, 2(1), 72-86.

Mc Quail, D. (1997). Teori Komunikasi Massa Suatu Pengantar. Jakarta: Erlangga.

Mukhlishoh, M., \& Khisbiyah, I. (2015). Pengaruh Media Film Animasi Terhadap Motivasi Belajar Siswa Mata Pelajaran IPA (Studi Penelitian di MI AN-NUR Kota Cirebon). Al Ibtida: Jurnal Pendidikan Guru MI, 2(2).

Mulyardi. (2006). Pengembangan Model Pembelajaran Matematika dalam Bentuk Komik pada Sekolah Dasar di Kota Padang. Penelitian Hibah Bersaing.

Netty. (2005). Pengaruh Penggunaan Media Komik Biologi Untuk Hasil Belajar Siswa Kelas II SMU Negeri 1 Angkat Candung Tahun Pelajaran 2005. Universitas Negeri Padang.

Nugroho, S. D. (2003). Pengaruh Penggunaan Media Kartun Fisika Terhadap Hasil Belajar Siswa Kelas I SLTPN 3 Batusangkar. Universitas Negeri Padang.

Riduan. (2005). Belajar Mudah Penelitian Untuk Guru, Karyawan, dan Peneliti Pemula. Bandung: Alfabeta.

Slameto. (2001). Evaluasi Pendidikan. Jakarta: Bumi Aksara.

Sudjana. (2001). Metode Statistika. Bandung: Tarsito. 
Sugiyono. (2006). Metode Penelitian

Pendidikan. Bandung: Alfabeta.

Surapranata, S. (2005). Analisis, Validitas,

Reliabilitas, dan Interpretasi Hasil Tes.

Bandung: Remaja Rosdakarya. 